\title{
Cumulative effects of 20 years of fire, grazing and selective tree cutting on soil water infiltration in sudanian savanna-woodland ecosystem of West Africa
}

\author{
Jonas KOALA $^{1 *}$, Patrice SAVADOGO ${ }^{2}$, Didier ZIDA ${ }^{1}$, Saïd MOHAMMED ${ }^{3}$, \\ Louis SAWADOGO ${ }^{1}$ and Hassan Bismarck NACRO ${ }^{4}$ \\ ${ }^{I}$ Centre National de Recherche Scientifique et Technologique (CNRST), \\ Institut de l'Environnement et de Recherches Agricoles (INERA), \\ Département Productions Forestières, 03 BP 7047, Ouagadougou 03, Burkina Faso. \\ ${ }^{2}$ World Agroforestry Centre \& International Crop Research Institute for the Semi-Arid Tropics (ICRAF- \\ ICRISAT), West and Central Africa Region-Sahel Node, BP 12404, Niamey, Niger. \\ ${ }^{3}$ International Livestock Research Institute (ILRI). P.O. Box 30709, Nairobi, Kenya. \\ ${ }^{4}$ Université de Bobo Dioulasso, Institut du Développement Rural, Laboratoire d'Etude et de Recherche sur la \\ Fertilité du Sol 01 BP 1091, Bobo Dioulasso, Burkina Faso. \\ *Corresponding author; E-mail: koalajonas@gmail.com, Tel: (+226)70309611
}

\begin{abstract}
Structural and functional dynamics of savanna-woodland ecosystems are mainly shaped by fire, grazing and wood removal which effects depends both on their intensities. The long-term effects of those disturbances on key soil parameters are still largely unknown. We studied the cumulative effect of 20 years of early fire, grazing and selective tree cutting on soil water infiltration at two experimental sites with contrasting soil conditions (deep silty-clay versus shallow silty-sand) in the sudanian savanna-woodland ecosystems of Burkina Faso. Measurements were carried with a single ring infiltrometer at intervals of 5, 10, 20 and 30 minutes. Results showed that Grazing had negative effect at both sites $(\mathrm{P}<0.0001)$. Fire has no effect on infiltration rate at deep soil whereas it has a negative effect on shallow one. Selective wood cutting had beneficial effects for infitration rate at the site with shallow soil. Further, all combined effect of the diffreent treatment resulted in decrease infiltration rate as compared with the control (interaction exclosure, no cutting and no fire). The result suggested that projects which aim to manage or improve soil water properties must take in consideration occurrence of disturbances, soils type and avoid disturbance interaction mainly in shallow sandy soils.
\end{abstract}

(C) 2014 International Formulae Group. All rights reserved.

Keywords: Disturbances, soil water properties, Burkina Faso, soil compaction, early fire, savanna ecosystem.

\section{INTRODUCTION}

In African savanna ecosystems, disturbance such as fire, grazing, and tree cutting are common (Bellefontaine et al., 2000; Sawadogo et al., 2002a). Their impacts on soil infiltration are different and are relative to their intensity. Effects of fire depend on burn severity, which consists of the highest temperature reached during the combustion and the duration of the fire event (Certini, 2005). Early fire in the dry season do not significantly affect steady state 
infiltrability, because the vegetation is still moist and less organic matter is destroyed (Diawara, 2012; Savadogo et al., 2012). Direct effect of moderate fires on physical properties is the creation of a discreet and continuous water-repellent front parallel to the surface that decreases soil permeability. Particle-size distribution is not directly affected by fires but, on steep surfaces, selective removal of the fine fraction through erosion can lead to soil coarsening (Certini, 2005). In terms of erosion, the combustion of vegetation and litter layer, which mitigate the impact of raindrops on soil and break runoff, often is more detrimental than water repellence (Certini, 2005). Combustion process converts the litter and duff layers into ash and charcoal. Ash and small soil particles can seal soil pores, decreasing the infiltration rate and increasing potential runoff and erosion. When the charcoal and ash are removed by post-fire runoff or wind, the soil is left bare soil to rain splash and overland flow (Martin and Moody, 2001).

Moderate grazing do not influence significantly infiltration while severe grazing consistently reduce infiltration ( Savadogo et al., 2007a). Reduction of infiltration rate by grazing occurs through two main mechanisms: soil compaction and vegetation cover disruption. Grazing decreases the infiltration rate by reducing vegetation cover and amount of organic matter in the topsoil. A decrease of organic matter content in the soil will lower macro-porosity, thereby reduces infiltrability (Savadogo et al., 2007). As for soil compaction, it is the process of increasing soil density by packing the particles closer together and reducing pore space. Soil compaction can reduce and disrupt soil porosity, and decrease water and air movement into and through the soil (Castellano and Valone, 2007). The result is poor soil aeration, poor root penetration, limited water movement and reduced activity of soil organisms involved in nutrient cycling. Soil compaction can also increase surface water runoff which may lead to soil erosion (Chartier et al., 2011).
Tree cutting may increase the risk of runoff because tree cover intercept rain and dissipate rainfall energy, reducing the volume and energy of rain reaching the ground. Water movement at the surface is slowed down by litter cover. This allows more water to infiltrate the soil, leaving less water to contribute to surface runoff (Bassey Eze et al., 2011).

Information on the long term effect of fire, grazing and selective cutting disturbance or their interactive effect on soil water properties is still lacking specially for West African dry savanna. Such knowledge is vital when developing guidelines for long-term management of savanna ecosystems (Savadogo et al., 2008). Previous studies have tended to focus on single factor such as fire, grazing and agriculture (Martin and Moody, 2001; Sadeghi et al., 2007; Savadogo et al., 2007a). Hence, this study examined soil water properties based on two factorial experimental sites established since 1992 to study the effect of common savanna disturbance on ecosystems function and structure (Savadogo et al., 2008).

This study aims at (i) evaluating long term impact of disturbances (fire, grazing and selective tree cutting) on soil infiltration at the two experimental sites characterized by shallow ( $<45 \mathrm{~cm}$ depth) silty-sand and deep $(>75 \mathrm{~cm})$ silty-clay; and to (ii) analyzing which factors promote infiltration and water storage in the soil.

\section{MATERIALS AND METHODS \\ Site description}

The experimental sites are located on flat areas in Laba $\left(11^{\circ} 40^{\prime} \mathrm{N}, 2^{\circ} 50 ' \mathrm{~W}\right)$ and Tiogo $\left(12^{\circ} 13^{\prime} \mathrm{N}, 2^{\circ} 42^{\prime} \mathrm{W}\right)$ State Forests (forêts classées), both at an altitude of $300 \mathrm{~m}$ a.s.l in Burkina Faso, West Africa (Figure 1). The Laba and Tiogo State Forests were delimited by the colonial French administration in 1936 and 1940 and cover 17 000 ha and 30000 ha, respectively. Both forests are located along the only permanent river (Mouhoun, formerly known as Black Volta) in the country. The unimodal rainy 
season lasts for about six months, from May to October. The mean annual rainfall during the study period $1992-2011$ was $916 \pm 158 \mathrm{~mm}$ at Laba and $837 \pm 158 \mathrm{~mm}$ at Tiogo. The number of rainy days per annum during the study period was $64 \pm 16$ at Laba and $62 \pm 12$ in Tiogo. Mean daily minimum and maximum temperatures ranged from $16{ }^{\circ} \mathrm{C}$ and $32{ }^{\circ} \mathrm{C}$ in January (the coldest month) and $26^{\circ} \mathrm{C}$ and 40 ${ }^{\circ} \mathrm{C}$ in April (the hottest month), yielding an aridity index of 0.32 and 0.29 for Laba and Tiogo, respectively. Most frequently encountered soils are Lixisols (Driessen et al., 2001). Soils in Laba are generally shallow ( $<45 \mathrm{~cm}$ depth) and the texture is $40 \%$ coarse sand, $17 \%$ clay, $17 \%$ fine sand, $16 \%$ coarse silt and $9 \%$ fine silt. In Tiogo, the soils are deep $(>75 \mathrm{~cm}$ ) and the texture $25 \%$ coarse silt, $25 \%$ clay, $22 \%$ fine sand, $15 \%$ fine silt and $13 \%$ coarse sand (Sawadogo et al., 2005). These soils are representative of large tracts of the Sudanian Zone in Burkina Faso (Driessen et al., 2001).

Phyto-geographically, the study sites are situated in the Sudanian regional centre of endemism in the transition from the north to south Sudanian Zone (Sawadogo, 2009). The vegetation type at both sites is a tree/bush savannah with a grass layer dominated by the annual grasses Andropogon pseudapricus Stapf. and Loudetia togoensis (Pilger) C.E. Hubbard as well as the perennial grasses Andropogon gayanus Kunth. (dominant in Tiogo) and Andropogon ascinodis C.B.Cl. (dominant in Laba). In the study area, these two perennial grasses are the most important species for fodder, construction (roofthatching and fences) and handicraft. The main forb species are Cochlospermum planchonii Hook. F., Borreria stachydea (DC.) Hutch. and Dalz., Borreria radiata DC. and Wissadula amplissima Linn. Species of the families Mimosaceae and Combretaceae dominate the woody vegetation component at both sites. In terms of basal area, the main woody species are Detarium microcarpum Guill. \& Perr., Combretum nigricans Lepr. ex Guill. \& Perr., Acacia macrostachya Reichenb. ex Benth., Entada africana Guill.
\& Perr., Lannea acida A. Rich., Anogeissus leiocarpa (DC.) Guill. \& Perr. and Vitellaria paradoxa C.F. Gaertn. At Laba experimental site, at the beginning of the study period the mean basal area of woody species at stump level $(20 \mathrm{~cm})$ was $10.7 \mathrm{~m}^{2} \mathrm{ha}^{-1}$ and $6.3 \mathrm{~m}^{2} \mathrm{ha}^{-1}$ at breast height $(130 \mathrm{~cm})$, and the stand density was 582 individuals ha $^{-1}$ having at least one stem $\geq 10 \mathrm{~cm} \mathrm{GBH}$ (girth at breast height). At Tiogo, the equivalent figures were $10.9 \mathrm{~m}^{2} \mathrm{ha}^{-1}$ at stump level, $6.1 \mathrm{~m}^{2} \mathrm{ha}^{-1}$ at breast height and 542 individuals $\mathrm{ha}^{-1}$.

Before the establishment of the experiment, the area was frequently grazed by livestock and wild animals and burnt almost every year, often late in the dry season (November to May). Livestock is dominated by cattle although sheep and goats also graze on these sites. The presence of livestock in the two state forests varies spatially and temporally, occurring mainly during the rainy season (June to October) when the grass is green and the surrounding areas are cultivated. During the dry season, when the crops are harvested, the cattle mostly frequent the agricultural fields and at this time of the year the animals come to the forest mostly in search of water along the river. They then graze on straws in the bush clumps that have escaped the fire as well as the young shoots of perennial grass species and young woody foliage induced by the fire. The mean herbaceous biomass production for the study period was $3.47 \pm 1.37 \mathrm{t} \mathrm{DMha}^{-1}$ at Laba site and $4.01 \pm 1.51 \mathrm{t} \mathrm{DM} \mathrm{ha}^{-1}$ for Tiogo (Sawadogo et al., 2005).

\section{Experimental design}

The design was factorial experiment that had been established in each of the two State forests to examine the effects of grazing, early fire, selective tree cutting and their interaction on ecosystem function and structure. In each experimental site (18 ha) we had four blocks (4.5 ha. Each of the four blocs was divided into two sub-blocs. One of the sub blocs was fenced to exclude livestock (hereafter referred to as non-grazed plots) and the contiguous other one was open for grazing 
(hereafter referred to as grazed plots). Each sub-block was further divided into nine plots of 0.25 ha $(50 \times 50 \mathrm{~m})$, separated from each other by $20-30 \mathrm{~m}$ fire-breaks (Savadogo et al., 2008). To the nine plots within each subblock, the following treatments were randomly assigned: no cutting - no fire, no cutting - early fire, cutting - no fire, and cutting - early fire. The selective cutting was done in December 1993 at Tiogo and a month later in January 1994 at Laba by removing $50 \%$ of the merchantable standing volume. Prior to cutting, all species were categorized according to their local uses as protected species, timber, poles and fuelwood, and others (Sawadogo, 2009). Except protected species, individuals of other categories were cut according to the following size criteria: > $30 \mathrm{~cm}$ butt diameter for timber species, $>14$ $\mathrm{cm}$ diameter at stump level for poles and fuelwood species and $>8 \mathrm{~cm}$ diameter at stump level for others (Sawadogo et al., 2002). The prescribed early fire was applied at the end of the rainy season (October November) each year beginning 1993 when the grass layer humidity was approximately $40 \%$. The grazing plots at both study sites were open for grazing by livestock (a mixed herd of cattle, sheep and goats). The livestock carrying capacity in Laba forest was 1.0 tropical livestock unit $\mathrm{ha}^{-1}$ (T.L.U. ha ${ }^{-1}$ ) and that of Tiogo was 1.4 T.L.U. ha ${ }^{-1}$ and the grazing pressure at both sites was about half of this capacity (Sawadogo et al., 2005) (Figure 2).

\section{Infiltration measurement}

Measurement was carried 2 months after the rain stopped with a single ring infiltrometer in 2011. The device was a cylinder of $10 \mathrm{~cm}$ diameter and $20 \mathrm{~cm}$ in height. Measurement was done once per plot at the center of the plot on a representative surface. Crack surfaces presenting macrospores are avoided. To ensure that the ring does not leak, it was fixed into the soil at a depth of $3 \mathrm{~cm}$ with the aid of a sledge hammer taking care not to disturb the soil surface too much. Any vegetation, litter and large stones from inside the ring were removed without disturbing the soil surface. When the soil surface was accidentally disturbed, the ring was reinstalled at another location. Before starting measurement process, soil was pre-wet with 2-3 litre of water. It was left to imbibe for at least 15-20 minutes. A ruler was placed along inner side of the cylinder, then, the same quantity of water used before to pre-wet the soil was slowly poured into the ring up to a level of about $17 \mathrm{~cm}$. Stop watch was then started and was not stopped during all the entire measurement period. Infiltration rates at the beginning of the test are quite variable, so for the first half-hour of the test we recorded at 5 minute intervals. After the first half hour, we recorded at 10 and 20 minute intervals for an additional 2 hours. At the end of each period and after each recording, water was topped up to the starting level. Readings were stopped after 150 minutes in all cases when a constant infiltration rate was reached.

\section{Data analysis}

All the data collected was used to calculate 2 variables: infiltration rate, and cumulative infiltration. Water depth in $\mathrm{mm}(\mathrm{fi})$ at each recording period that represent cumulative infiltration in this period was calculated as

$$
f i(t)=Q n-Q 0
$$

With $f i(t)$ cumulative infiltration (in $\mathrm{mm})$ in each measurement period, $Q n=$ water level at the end the period and $Q O=$ water level at the beginning.

Further, measurements of steady infiltration rate were made after each measurement period in dividing the cumulative infiltration water depth for the period by the required times (Wuest, 2005).

$$
r i(t)=\frac{f i(t)}{t}
$$

With $\mathrm{ri}(\mathrm{t})=$ infiltration rate (in $\mathrm{mm} / \mathrm{min}$ ) at each recording period, $t=$ time of this period and $f i(t)$, the cumulative infiltration in this period (in $\mathrm{mm}$ ). 
And total infiltration rate was calculated as the mean of all ri(t) using the following equation.

$$
r(t)=\frac{\sum_{t_{0}}^{t} r i(t)}{n}
$$

By integrating equation 1 , we calculated total cumulative infiltration $(\mathrm{C}(\mathrm{t}))$ for each measurement point.

$$
C(t)=\int_{t 0}^{t} f i(t) \cdot d t
$$

Data was examined with an emphasis on comparing infiltration rate and cumulative infiltration due to soil difference, the separate effect of fire, grazing and selective cutting and treatments combination. The different plots and blocs in the two sites were not of particular interest here since they were considered as random effect.

Data was not normally distributed, but we avoided data transformation as a solution to met assumption of parametric analysis considered mostly as more robust, because some interesting ecological information could be thrown away (Zuur et al., 2009). Therefore, non parametric analysis was used for data analysis. Marginal means and different confidence intervals of each variable (infiltration rate and cumulative infiltration) for each treatment were estimated and Kruskal-Wallis test was used to compare variation of the two infiltration parameters. All statistical analyses were done with SPSS 22 software package (Copyright SPSS for Windows, Release 2013: IBM corporation).

\section{RESULTS}

\section{Treatments main effect on infiltration rate and cumulative infiltration Infiltration rate}

There was a highly significant difference $[(\chi 2(1,139)=625.3, \mathrm{p}<0.001)]$ between studied sites for infiltration rate. As expected, Laba where the soils were mostly sandy had higher steady infiltration rate $\left(209.5 \pm 168.6 \mathrm{~mm} \cdot \mathrm{h}^{-1}\right)$ than the clay soils of Tiogo $\left(71.3 \pm 56.4 \mathrm{~mm} \cdot \mathrm{h}^{-1}\right)$ (Figure 3a). Infiltration rate ranged from $199.1 \mathrm{~mm} \cdot \mathrm{h}^{-1}$ to $219.9 \mathrm{~mm} \cdot \mathrm{h}^{-1}$ in Laba and 68 to $74.7 \mathrm{~mm} \cdot \mathrm{h}^{-1}$ in Tiogo (Table 1).
Kruskal-Wallis test revealed a statistically significant decreasing effect of moderate grazing on infiltration rate both at Laba $[(\chi 2(1,68)=150.4, p<0.001)]$ and Tiogo $[(\chi 2(1,71)=113.6, p<0.001)]$. In Laba and Tiogo, infiltration rate in grazing exclosure (respectively $259.4 \pm 178.2$ and $82.1 \pm 50.5$ $\mathrm{mm} \cdot \mathrm{h}^{-1}$ ) were higher than the value recorded for plots subject to moderate grazing (respectively $153.4 \pm 142.4$ and $60.9 \pm 59.8$ mm. $\mathrm{h}^{-1}$ ) (Figure 3b). In Laba infiltration rates in exclosure were nearly doubling those in the open grazing and ranged respectively from 244.3 to $274.5 \mathrm{~mm} \cdot \mathrm{h}^{-1}$ and from 141.1 to $165.6 \mathrm{~mm} \cdot \mathrm{h}^{-1}$. In Tiogo, the value ranged from 77.8 to 86.4 and from 55.9 to 66.0 respectively in exclosure and open grazing plots (Table 1).

Selective tree cutting effects differed following the sites. In Laba (sandy soil) its effect was significant $\left[\left(\chi^{2}(1,68)=27.8\right.\right.$, $\mathrm{p}<0.001$ )] and positive (Figure 3c). Infiltration rate in plots subject to selective cutting (226.9 $\pm 176.6 \mathrm{~mm}$.h-1) was higher than the one of the pots where there was no cutting (175.6 \pm $146.0 \mathrm{~mm} . \mathrm{h}-1)$. In contrary in Tiogo, selective wood cutting had a reducing effect $[(\chi 2(1,71)$ $=09.8, \mathrm{p}=0.002)]$; the plots submitted to selective cutting $(64.2 \pm 38.9$ mm.h-1) had lower infiltration rate than those without cutting $(86.3 \pm 79.6$ mm.h-1) (Table 1).

There was site specificity in terms of early fire effect on infiltration rate. In Laba early fire affected significantly $\left[\left(\chi^{2}(1,68)\right.\right.$ $=7.6, p=0.04)]$ and negatively infiltration rate (Figure 3d). Plots subject to early fire had infiltration ranging from 182.0 to $203.7 \mathrm{~mm} . \mathrm{h}^{-}$ ${ }^{1}$ that was lower than the unburnt plots in which infiltration rate ranged from 220.3 to $263.9 \mathrm{~mm} \cdot \mathrm{h}^{-1}$. In Tiogo there was no difference between burnt plots and unburnt ones $\left[\left(\chi^{2}(1,71)=0.55, \mathrm{p}=0.46\right)\right]$ that had infiltration rates ranging respectively from 68.4 to $77.6 \mathrm{~mm} \cdot \mathrm{h}^{-1}$ and from 63.7 to 72.1 $\mathrm{mm} \cdot \mathrm{h}^{-1}$ (Table 1).

\section{Cumulative infiltration}

As for the infiltration rate, significant site variation was observed for the cumulative infiltration $\left[\left(\chi^{2}(1,139)=319.9, \mathrm{p}<0.001\right)\right]$. 
The site with shallow silty-sandy soil (Laba) had more accumulated water during the measurement period than the deep silty-clay soils in Tiogo (Figure 5a). During the measurement period (150 minutes) the water accumulated per unit of area $\left(3.14 \times 10^{-2} \mathrm{~m}^{2}\right)$ in Laba was substantially higher (varying from 401.3 to $573.8 \mathrm{~mm}$ ) than the value recorded in Tiogo which ranged ranged from 140.5 to $204.7 \mathrm{~mm}$ (Table 1).

The main effect of grazing on cumulative infiltration was not differing between the sites. In Laba $[(\chi 2(1,68)=84.4$, $\mathrm{p}<0.001)]$ as in tiogo $[(\chi 2(1,71)=40,5$, $\mathrm{p}<0.001)$, exclosure had higher cumulative infiltration than the open grazing plots (figure 5b). For Laba's site, at $95 \%$, the confidence interval ranged from 476.6 to $724.8 \mathrm{~mm}$ after 150 minutes in exclosure against 251.6 to $468.9 \mathrm{~mm}$ in grazed plots. Whereas in Tiogo, the ranges observed in the exclosure and grazed plots were respectively 159.4 to 246.8 $\mathrm{mm}$ and 96.0 to $189.9 \mathrm{~mm}$, (Table 1 ).

Selective tree cutting affected cumulative infiltration positively on shallow silty-sandy soil (Laba) $[(\chi 2(1,68)=15.2$, $\mathrm{p}<0.001)]$ and negatively on deep silty-clay soil $($ Tiogo $)[(\chi 2(1,71)=07.7, \mathrm{p}=0.005)]$ (Figure 5c). The mean height of water infiltrated during the measurement period in selective tree cutting plots and no cutting plots were respectively 414.2 to $628.3 \mathrm{~mm}$ and 268.2 to $575.1 \mathrm{~mm}$ in Laba and in the same order 127.0 to $178.5 \mathrm{~mm}$ and 128.5 to 299.6 $\mathrm{mm}$ (Table 1).

Similarly, the early fire treatment did not affect significantly water accumulation at either experimental site (Figure 5d). The mean height of water infiltrated during the measurement period in burnt plots and unburnt plots ranged respectively from 360.8 to $535.9 \mathrm{~mm}$ and 367.2 to $761.3 \mathrm{~mm}$ in Laba $[(\chi 2(1,68)=2.15, \mathrm{p}=0.143)]$, and in the same order from 131.7 .6 to $214.8 \mathrm{~mm}$ and 118.7 to $223.9 \mathrm{~mm}$ in Tiogo $[(\chi 2(1,71)=0.8$, $\mathrm{p}=0.777)$ ] (Table 1).

\section{Treatment combination effect on infiltration rate and cumulative infiltration Infiltration rate}

At the two sites, Kruskal-Wallis test revealed significant interaction between the three factors (grazing, selective cutting and early fire). The combined effect of the treatments resulted in decreasing infiltration rate depending on the factors involved. In Laba, all treatments combination had lower $[(\chi 2(6,68)=281.9, \mathrm{p}<0.001)]$ infiltration rate compared with the control (438.3 \pm 118.3 $\mathrm{mm} \cdot \mathrm{h}^{-1}$ ) (Figure 7 ). In this site the lowest infiltration rates was obtained in the following combined treatment: grazing + selective cutting + no fire $\left(120.9 \pm 123.7 \mathrm{~mm} \cdot \mathrm{h}^{-1}\right)$, grazing + no cutting + early fire $(110.6 \pm 76.2$ $\left.\mathrm{mm} \cdot \mathrm{h}^{-1}\right)$ and interaction grazing + no selective cutting + no fire $\left(84.4 \pm 59.0 \mathrm{~mm} \cdot \mathrm{h}^{-1}\right)$ (Figure 4). However in Tiogo $[(\chi 2(6,71)=216.2$, $\mathrm{p}<0.001)]$, only the combined effect of grazing + cutting + early fire $(41.4 \pm 24.5$ $\left.\mathrm{mm} \cdot \mathrm{h}^{-1}\right)$ and grazing + no selective cutting + no fire $\left(41.1 \pm 17.0 \mathrm{~mm} \cdot \mathrm{h}^{-1}\right)$ had lower infiltration rate compare to the control $(70,9 \pm$ $35,9 \mathrm{~mm} \cdot \mathrm{h}^{-1}$ ). The others interactions did not differ from the control (Table 2).

\section{Cumulative infiltration}

At the two sites, Kruskal-Wallis test revealed significant interaction between the three factors (grazing, selective cutting and early fire) (Figure 8). On shallow silty-sandy soil the combined effect of grazing + no cutting + no fire had the largest negative effect $[(\chi 2(6,68)=180.1, p<0.001)]$ on cumulative infiltration $(194.8 \pm 164.5 \mathrm{~mm})$ as compared with all other treatment including the control, while on deep silty-clay soil [ $(\chi 2$ $(6,68)=80.6, \mathrm{p}<0.001)]$ the outstanding lowest treatment combinations in terms of cumulative infiltration were grazing + selective tree cutting + early fire $(98.9 \pm 54.3$ $\mathrm{mm})$ and grazing + no cutting + no fire $(87.1$ $\pm 37.8 \mathrm{~mm}$ ) (Figure 6). 
Table 1 : Estimated marginal mean with standard deviation (mean \pm SD) and confidence intervals of infiltration rate and cumulative infiltration at two sites Laba (shallow silty-sand) and Tiogo (deep silty-clay) in the savanna-woodland subject to grazing, selective tree cutting, and early fire in Sudanian savanna-woodland in Burkina Faso (West Africa).

\begin{tabular}{|c|c|c|c|c|c|c|c|c|c|}
\hline \multirow[t]{2}{*}{ Sites } & \multirow[t]{2}{*}{ Treatment } & \multirow[t]{2}{*}{$\mathbf{N}$} & \multirow{2}{*}{$\begin{array}{c}\text { Infiltration rate } \\
(\mathrm{mm} / \text { hour })(\text { Mean } \pm \mathrm{SD}) \\
\end{array}$} & \multicolumn{2}{|c|}{ CI at $95 \%$} & \multirow[t]{2}{*}{$\mathbf{N}$} & \multirow{2}{*}{$\begin{array}{c}\text { Cumulative infiltration } \\
(\mathrm{mm})(\text { Mean } \pm \text { SD })\end{array}$} & \multicolumn{2}{|c|}{ CI at $95 \%$} \\
\hline & & & & $\mathbf{L L}$ & UL & & & $\mathbf{L L}$ & $\mathbf{U L}$ \\
\hline \multirow{6}{*}{ Laba } & Early fire & 45 & $192.8 \pm 143.2 \mathrm{~b}$ & 182.0 & 203.7 & 45 & $448.3 \pm 291.3 \mathrm{~b}$ & 360.8 & 535.9 \\
\hline & No fire & 23 & $242.1 \pm 205.9 \mathrm{a}$ & 220.3 & 263.9 & 23 & $564.3 \pm 455.7 \mathrm{~b}$ & 367.2 & 761.3 \\
\hline & Open grazing & 32 & $153.4 \pm 142.4 \mathrm{~b}$ & 141.1 & 165.6 & 32 & $360.3 \pm 301.4 \mathrm{~b}$ & 251.6 & 468.9 \\
\hline & Exclosure & 36 & $259.4 \pm 178.2 \mathrm{a}$ & 244.3 & 274.5 & 36 & $600.7 \pm 366.9 \mathrm{a}$ & 476.6 & 724.8 \\
\hline & Selective cutting & 45 & $226.9 \pm 176.6 \mathrm{a}$ & 213.5 & 240.2 & 45 & $521.2 \pm 356.3 \mathrm{a}$ & 414.2 & 628.3 \\
\hline & No cutting & 23 & $175.6 \pm 146.0 \mathrm{~b}$ & 160.1 & 191.0 & 23 & $421.7 \pm 354.8 \mathrm{~b}$ & 268.2 & 575.1 \\
\hline \multirow{6}{*}{ Tiogo } & Early fire & 48 & $73.0 \pm 62.8 \mathrm{~d}$ & 68.4 & 77.6 & 48 & $173.2 \pm 143.1 \mathrm{c}$ & 131.7 & 214.8 \\
\hline & No fire & 23 & $67.9 \pm 39 \mathrm{de}$ & 63.7 & 72.1 & 23 & $171.3 \pm 121.6 \mathrm{c}$ & 118.7 & 223.9 \\
\hline & Open grazing & 36 & $60.9 \pm 59.8 \mathrm{e}$ & 55.9 & 66.0 & 36 & $143.0 \pm 138.8 \mathrm{~d}$ & 96.0 & 189.9 \\
\hline & Exclosure & 35 & $82.1 \pm 50.5 \mathrm{c}$ & 77.8 & 86.4 & 35 & $203.1 \pm 127.1 \mathrm{c}$ & 159.4 & 246.8 \\
\hline & Selective cutting & 48 & $64.2 \pm 38.9 \mathrm{e}$ & 61.3 & 67.0 & 48 & $152.7 \pm 88.6 \mathrm{~d}$ & 127.0 & 178.5 \\
\hline & No cutting & 23 & $86.3 \pm 79.6 \mathrm{c}$ & 77.9 & 94.7 & 23 & $214.1 \pm 197.8 \mathrm{c}$ & 128.5 & 299.6 \\
\hline
\end{tabular}


J. KOALA et al. / Int. J. Biol. Chem. Sci. 8(6): 2424-2440, 2014

Table 2: Estimated marginal mean with standard deviation (mean \pm SD) and confidence intervals of infiltration rate and cumulative infiltration at two sites Laba (shallow silty-sand) and Tiogo (deep silty-clay) in the savanna-woodland subject to cumulative effect of grazing, selective tree cutting, and early fire in Sudanian savanna-woodland in Burkina Faso (West Africa).

\begin{tabular}{|c|c|c|c|c|c|c|c|c|c|}
\hline \multirow[t]{2}{*}{ Sites } & & \multirow[t]{2}{*}{$\mathbf{N}$} & \multirow{2}{*}{$\begin{array}{c}\text { Infiltration rate } \\
(\mathrm{mm} / \text { hour })(\text { Mean } \pm \mathrm{SD})\end{array}$} & \multicolumn{2}{|c|}{ CI at $95 \%$} & \multirow[t]{2}{*}{$\mathbf{N}$} & \multirow{2}{*}{$\begin{array}{l}\text { Cumulative infiltration }(\mathrm{mm}) \\
(\text { Mean } \pm \text { SD) }\end{array}$} & \multicolumn{2}{|c|}{ CI at $95 \%$} \\
\hline & & & & $\mathbf{L L}$ & $\mathbf{U L}$ & & & $\mathbf{L L}$ & $\mathbf{U L}$ \\
\hline \multirow{8}{*}{ Laba } & $\mathrm{G} \times \mathrm{C} \times \mathrm{F}$ & 14 & $210.7 \pm 159.26 \mathrm{c}$ & 189.0 & 232.4 & 14 & $485.5 \pm 341.0 \mathrm{c}$ & 288.6 & 682.4 \\
\hline & $\mathrm{G} \times \mathrm{C} \times \mathrm{nF}$ & 7 & $120.9 \pm 123.7 \mathrm{de}$ & 96.9 & 144.8 & 7 & $295.4 \pm 313.3 \mathrm{f}$ & 5.6 & 585.1 \\
\hline & $\mathrm{G} \times \mathrm{nC} \times \mathrm{F}$ & 7 & $110.6 \pm 76.2 \mathrm{ef}$ & 95.9 & 125.4 & 7 & $269.3 \pm 190.2 \mathrm{e}$ & 93.3 & 445.2 \\
\hline & $\mathrm{G} \times \mathrm{nC} \times \mathrm{nF}$ & 4 & $84.4 \pm 59.0 \mathrm{f}$ & 69.1 & 99.6 & 4 & $194.8 \pm 164.5 \mathrm{~g}$ & 67.0 & 456.5 \\
\hline & $\mathrm{E} \times \mathrm{C} \times \mathrm{F}$ & 16 & $234.3 \pm 154.7 \mathrm{c}$ & 214.6 & 253.9 & 16 & $536.6 \pm 291.9 \mathrm{c}$ & 381.1 & 692.2 \\
\hline & Ex C x nF & 8 & $333.1 \pm 221.0 \mathrm{~b}$ & 293.1 & 373.0 & 8 & $750.6 \pm 448.4 \mathrm{~b}$ & 375.7 & 1125.4 \\
\hline & $\mathrm{E} \times \mathrm{nC} \times \mathrm{F}$ & 8 & $150.6 \pm 81.3 \mathrm{~d}$ & 135.9 & 165.3 & 8 & $363.4 \pm 207.1 \mathrm{~d}$ & 190.3 & 536.6 \\
\hline & Control & 4 & $430.3 \pm 118.3 \mathrm{a}$ & 399.7 & 460.8 & 4 & $1031.8 \pm 309.0 \mathrm{a}$ & 540.1 & 1523.4 \\
\hline \multirow{8}{*}{ Tiogo } & $\mathrm{G} \times \mathrm{C} \times \mathrm{F}$ & 16 & $41.4 \pm 24.5 \mathrm{~g}$ & 38.3 & 44.6 & 16 & $98.9 \pm 54.2 \mathrm{~h}$ & 70.1 & 127.8 \\
\hline & $\mathrm{G} \times \mathrm{C} \times \mathrm{nF}$ & 8 & $64.8 \pm 38.7 \mathrm{f}$ & 57.8 & 71.8 & 8 & $152.1 \pm 90.5 \mathrm{~g}$ & 76.4 & 227.8 \\
\hline & $\mathrm{G} \times \mathrm{nC} \times \mathrm{F}$ & 8 & $105.9 \pm 101.6 \mathrm{de}$ & 87.5 & 124.3 & 8 & $249.8248 .8 f$ & 41.8 & 457.7 \\
\hline & $\mathrm{G} \times \mathrm{nC} \times \mathrm{nF}$ & 4 & $41.1 \pm 17.0 \mathrm{~g}$ & 36.7 & 45.4 & 4 & $87.1 \pm 37.8 \mathrm{~h}$ & 27.0 & 147.3 \\
\hline & $\mathrm{E} \times \mathrm{C} \times \mathrm{F}$ & 16 & $77.1 \pm 38.3 \mathrm{f}$ & 72.2 & 81.9 & 16 & $183.3 \pm 86.9 \mathrm{f}$ & 137.0 & 229.6 \\
\hline & $\mathrm{E} \times \mathrm{C} \times \mathrm{nF}$ & 8 & $83.3 \pm 42.0 \mathrm{f}$ & 75.7 & 90.9 & 8 & $199.9 \pm 103.9 \mathrm{f}$ & 113.1 & 286.8 \\
\hline & $\mathrm{E} \times \mathrm{nC} \times \mathrm{F}$ & 8 & $95.1 \pm 76.0 \mathrm{de}$ & 81.4 & 108.9 & 8 & $225.3 \pm 174.8 \mathrm{f}$ & 79.1 & 371.4 \\
\hline & Control & 3 & $70.9 \pm 35.9 \mathrm{f}$ & 60.1 & 81.7 & 3 & $258.3 \pm 252.4 \mathrm{f}$ & 368.7 & 885.4 \\
\hline
\end{tabular}




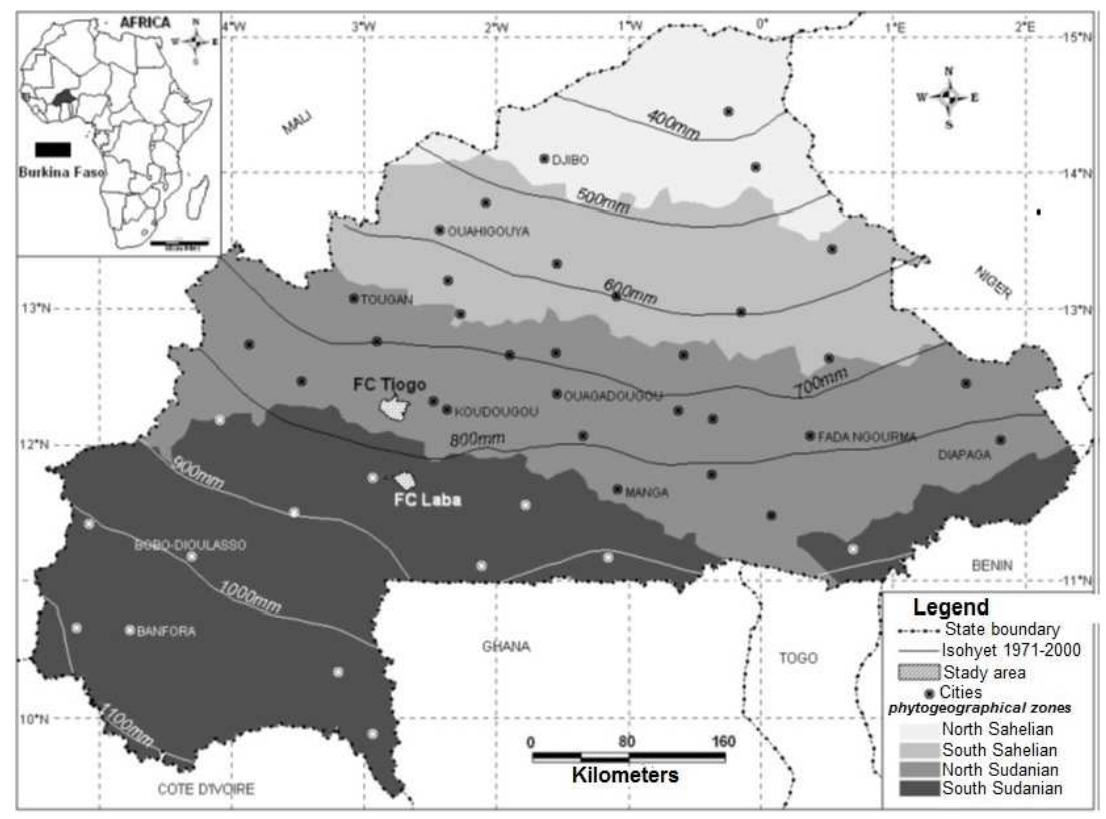

Figure 1: Location of Laba and Tiogo forests in vegetation and isohyets map of Burkina Faso (Readapted April 2007 by CTIG/INERA, Burkina Faso after Fontes \& Guinko 1995 and Direction of the National Meteorology).

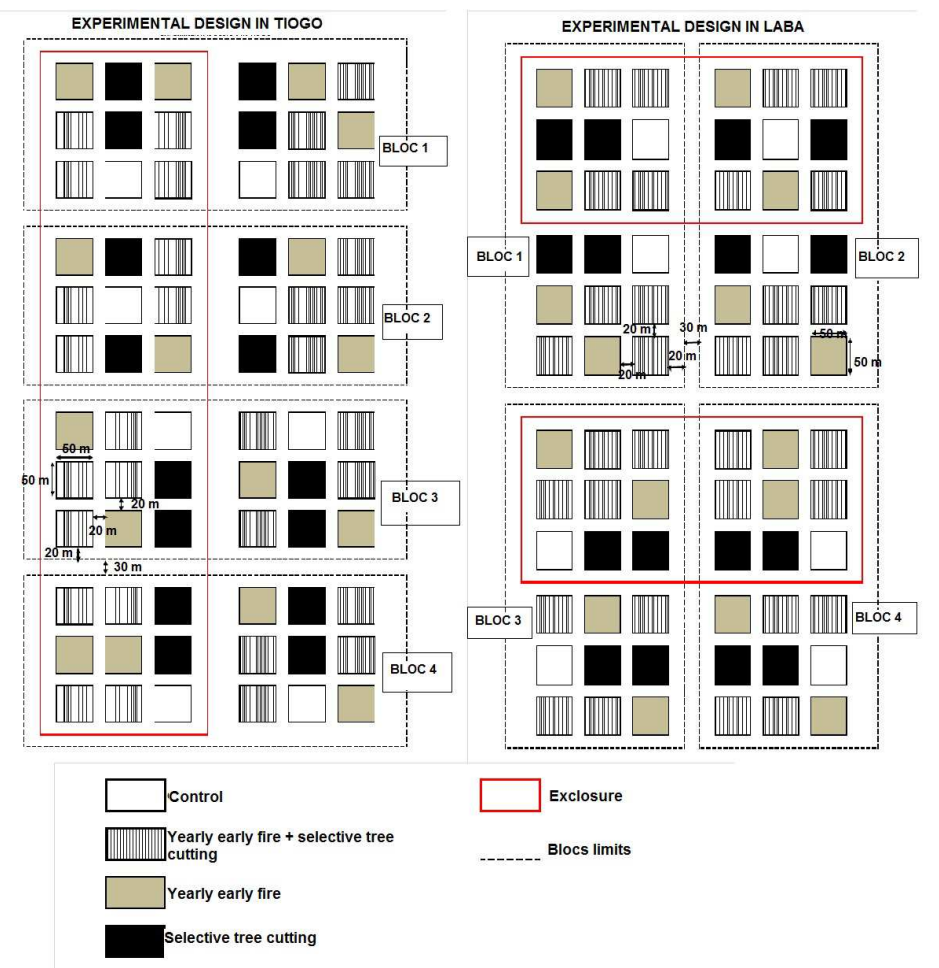

Figure 2: Experiment design in Laba and Tiogo. 


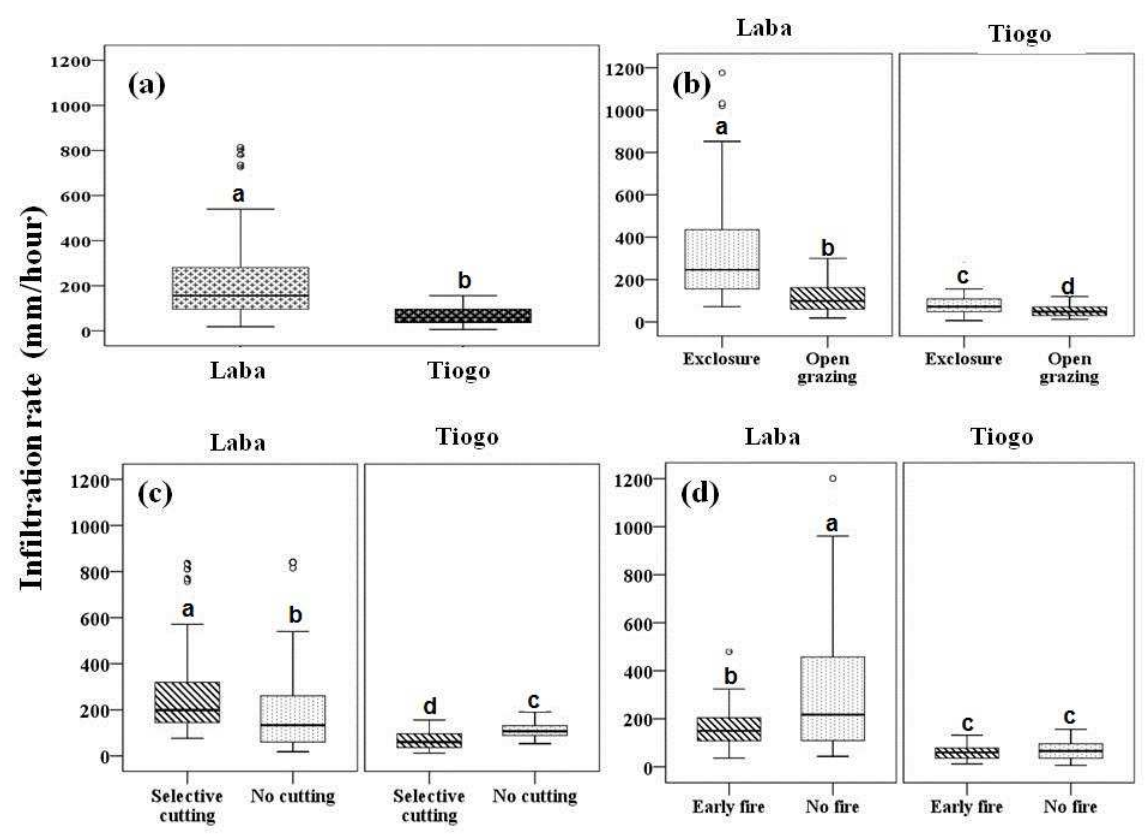

Figure 3 : Site difference (a), grazing and grazing enclosure (b) selective tree cutting and no cutting (c) and early fire no burning effect on soil water infiltration rate after 20-year of treatment application. In each sub-figure (a, b,c and d), infiltration rate values with the same letter are not significantly different $(\mathrm{P}>0.05)$.

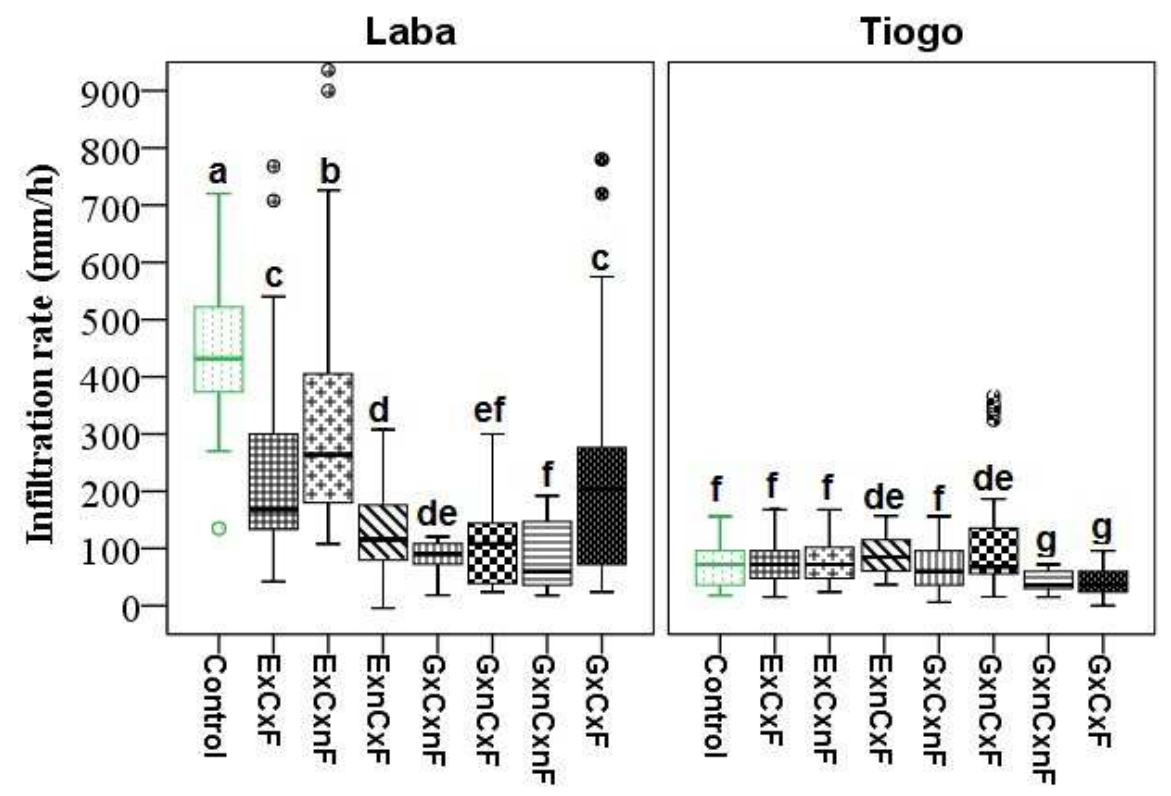

Figure 4 : Combination effect of grazing, selective tree cutting and fire on infiltration rate in sandy (Laba) and clay (Tiogo) soils in savannah woodland. E= Exclosure, G= Open grazing, C=selective trees cutting, $\mathrm{nC}=$ No cutting, $\mathrm{F}=$ Yearly early fire and $\mathrm{nF}=\mathrm{No}$ fire. Infiltration rate values with the same letter are not significantly different $(\mathrm{P}>0.05)$. 

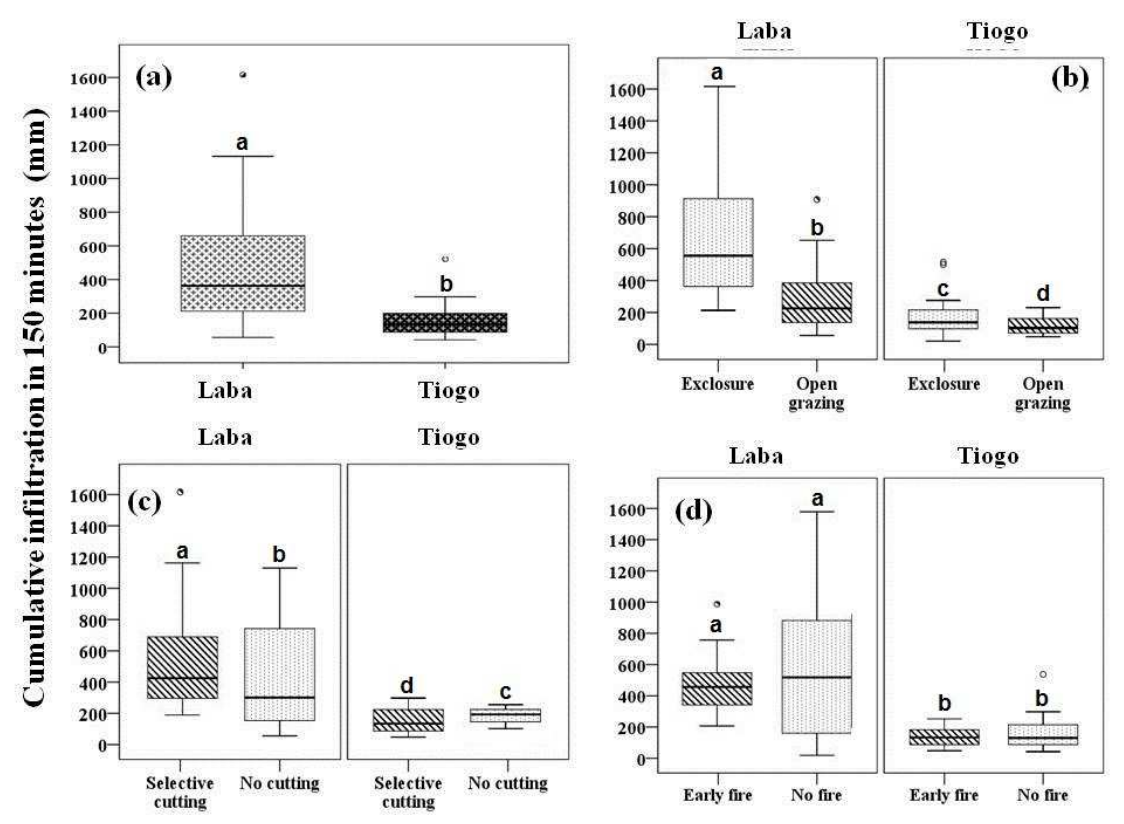

Figure 5: Site difference (a), grazing and grazing enclosure (b) selective tree cutting and no cutting (c) early fire and no burning (d) effect on soil cumulative water infiltration after 20-year of treatment application. In each sub-figure ( $a, b, c$ and $d)$, cumulative infiltration values with the same letter are not significantly different $(\mathrm{P}>0.05)$.

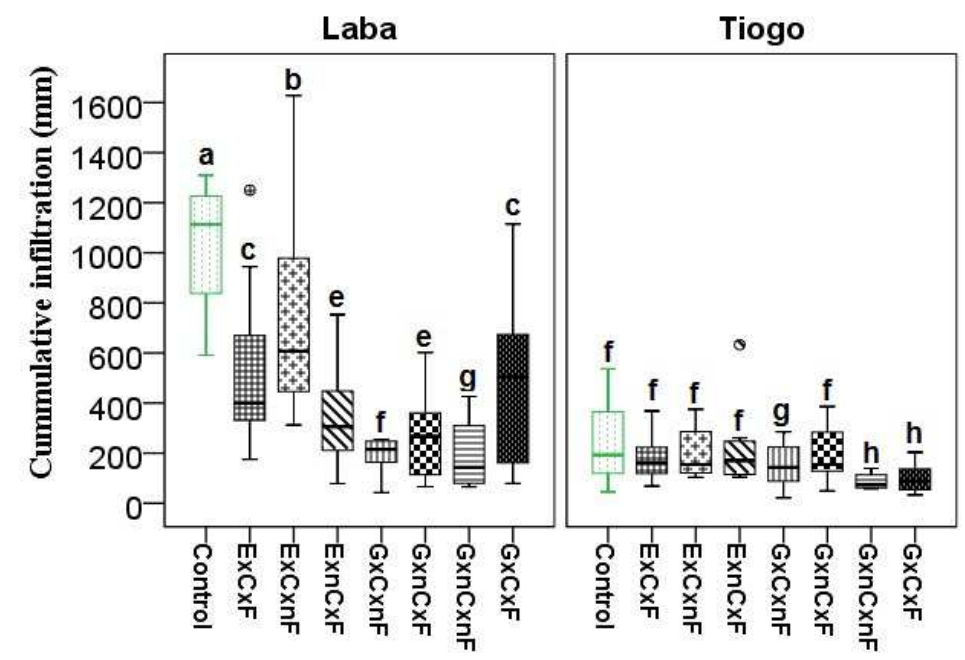

Figure 6: Combined effect of grazing. Selective tree cutting and early fire on cumulative infiltration at Laba (shallow silty-sandy soil) and Tiogo (deep silty-clay soil) in savanna- woodland in Burkina Faso. $\mathrm{E}=$ Exclosure. $\mathrm{G}=$ Open grazing. $\mathrm{C}=$ selective trees cutting. $\mathrm{nC}=\mathrm{No}$ cutting. $\mathrm{F}=$ Yearly early fire and $\mathrm{nF}=$ No fire. Cumulative infiltration values with the same letter are not significantly different $(\mathrm{P}<0.05)$. 

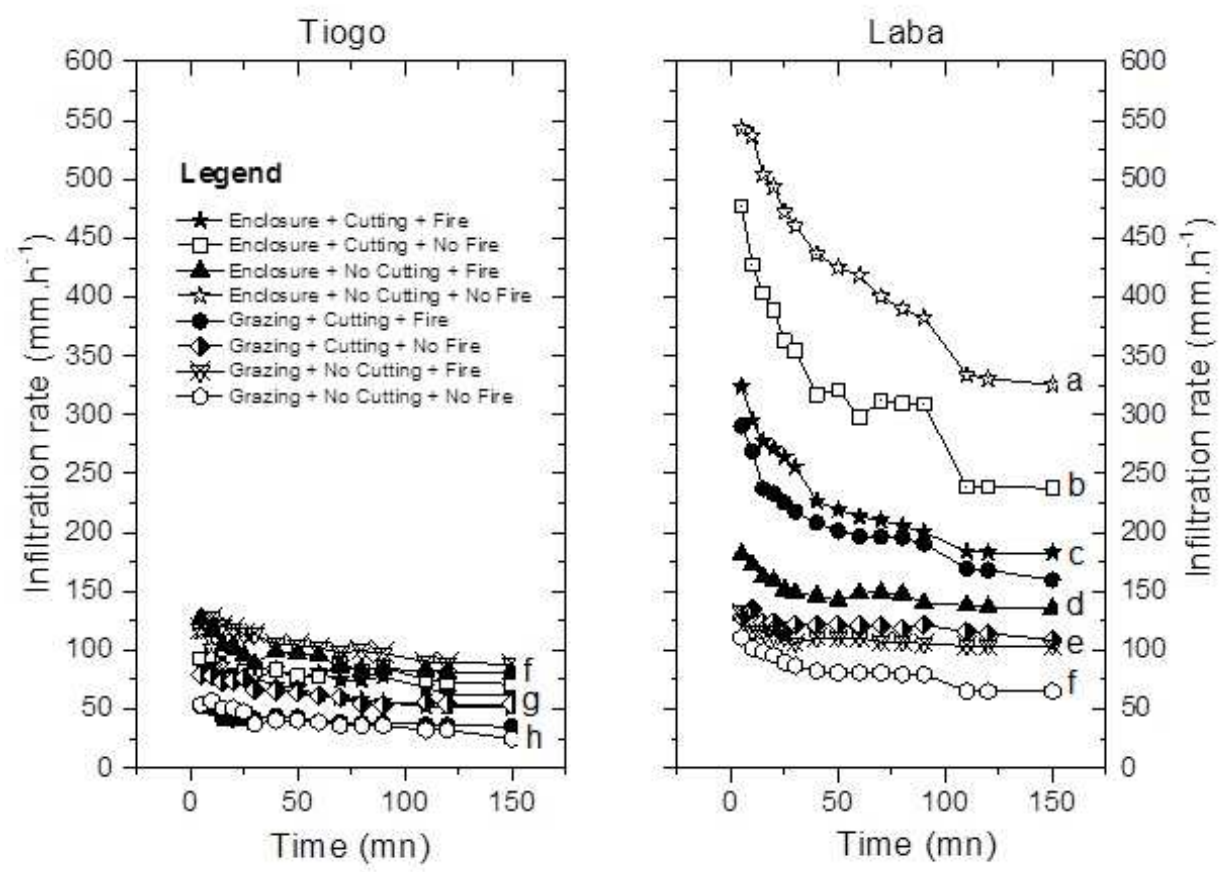

Figure 7: Steady Infiltration rate as function of time (minute) at Laba (shallow silty-sandy soil) and Tiogo (deep silty-clay soil) in the sudanian savanna wood-land of Burkina Faso. Curves related to the same letter are not significantly different $(\mathrm{P}>0.05)$.
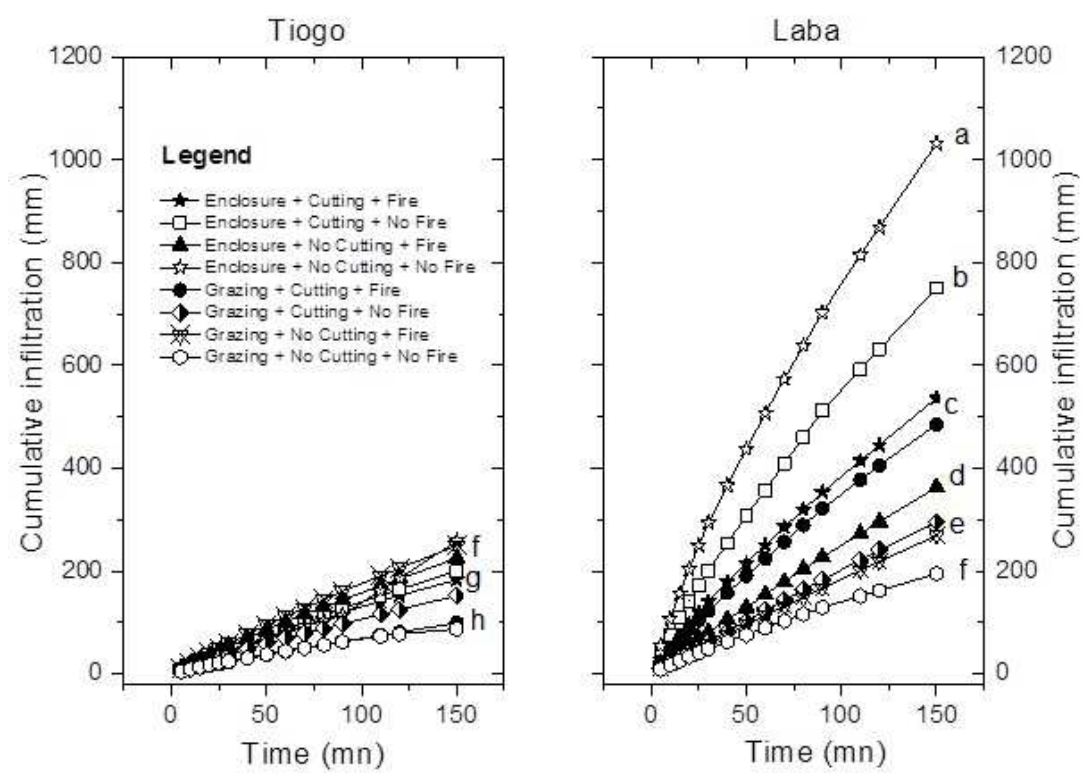

Figure 8: Cumulative infiltration as function of time (minute) at Laba (shallow silty-sandy soil) and Tiogo (deep silty-clay soil) in the sudanian savanna wood-land of Burkina Faso. Curves related to the same letter are not significantly different $(\mathrm{P}>0.05)$. 


\section{DISCUSSION}

Mean effect of the treatments on infiltration rate and cumulative infiltration Soils types

This study indicated that the different factors affect differently steady infiltration and that there was site difference in terms of soil water properties. Infiltration rate was higher in plot in Laba characterized by sandy soil than those in Tiogo where soils are mostly clay. The trend of infiltration between the two sites is most likely explained by soil physical properties (Zhou et al., 2010). Largest particles held by soils in Laba allow more aeration and drainage than the tiniest submicroscopic clay particles in Tiogo. This results suggest clay soils are more sensitive to soils erosion as infiltration rate is negatively correlate with soils erodibility (Zhou et al., 2010).

Grazing

Grazing pressure was the half of the carrying capacity of the two forest (Sawadogo, 2006) that was as 1.0 tropical livestock unit ha ${ }^{-1}$ (T.L.U. ha ${ }^{-1}$ ) in Laba forest and 1.4 T.L.U. ha ${ }^{-1}$ in Tiogo (Savadogo et al., 2008). Effect of grazing on the steady state infiltrability was significant in the two sites; the subplots without grazing had a large infiltration rate which indicates the importance of livestock management on soil hydrology. Several studies report similar results (Sadeghi et al., 2007; Zhou et al., 2010). However, these results contrast with findings by Beukes and Cowling, (2003) who indicated improvement of soil stability and increased infiltration rate in moderate grazing environment. Cattle grazing results in mechanical pressure on the ground as animal trampling contributes to altered soil structure through soil compaction and reduction of soil porosity (Pietola et al., 2004; Dunne et al., 2011; Kölbl et al., 2011). Grazing increased the bulk density of the top horizon at varying stocking rates (Chaichi et al., 2005). Grazing also decreases the infiltration rate by reducing vegetation cover and amount of organic matter in the soil (Savadogo et al., 2007a; Chartier et al., 2011).

\section{Selective tree cutting}

Our results show that the overall main effect of selective cutting of trees was significant and negative at the deep silty-clay soil of Tiogo and significant and positive effect at the site of Laba characterized by shallow silty-sandy soil. Selective removal of trees is thought to open up gap and increasing the availability of light at the ground level (Makana and Thomas, 2005; Wagner et al., 2011) thus create unfavorable thermal condition in the understory that increases soil evaporation. This may explain the reduction of infiltration rate found in Tiogo which is in agreement with studies by Chartier et al., (2011) that reported decrease in infiltration rate in conditions with vegetation cover reduction. However, this observation is contrasting with the finding on the silty-sandy soil of Laba were selective cutting increased infiltration rate. It should be noted that the selective cutting treatment was applied once by extracting $50 \%$ of the basal area of all trees, Increasing of infiltration in these plots may prove that vegetation has recovered after cutting or even has been improved comparatively to its initial state.

\section{Early fire}

There was site specificity in terms of early fire effect on infiltration rate. In Tiogo, there was no difference between burnt plots and unburnt ones while in Laba it affected significantly and negatively infiltration rate. Generally, fires modify plant-soil environment. The negative effects of fire on infiltration rate are reported by many studies (Martin and Moody, 2001; Savadogo et al., 2007a; Vega et al., 2008; Are et al., 2009). This is primarily related to the destructive effect of fire on above ground living biomass and litter. Prescribed burn operations attempt to leave sites with the surface condition of a low severity burn. However, some of the areas often experience surface conditions associated with a high-severity burn which may result in hydrophobic or water repellent conditions (DeBano, 2000). Moreover, surface biomass consumption by fire increase the exposure of the soil surface to the impact of raindrops 
which in turn often leads to crusting. The mechanical energy input from raindrops increases the dispersion of soils and results in the blockage of surface pores and reduced infiltration in most soil types ( Savadogo et al., 2007a; Are et al., 2009). This results contrast with the present result where the effect of fire was not significant at Tiogo (clay soil) site. Nevertheless the results are consistent with those of Diawara (2012) which indicate the same trend for data collected at the same site. That is due to the fact that in this experiment, the prescribed early fire is a light surface fire and only leads to partial combustion because of high moisture content in the vegetation (Diawara, 2012). The contrasting effect between the two sites suggest that the practices of prescribed early fire generally used as better compromise between protections from fire and late burning may be redefine in order to take in consideration sites conditions

Combined effect of treatments on infiltration rate and cumulative infiltration At the silty-sandy soil of Laba all treatment combinations had reduced soil water infiltration. The combined effects of fire, grazing and selective tree cutting could have resulted from independent effect of each treatment or from the fact that additive effect could occur. Fire may have simply duplicated the effect of grazing by reducing above ground biomass. Indeed, Combination of negative effect on vegetation and litter cover, soil heating by fire and livestock trampling enhance the additive effects of the three factors and could affect soil stability and soil fauna. Indeed. cattle grazing results in mechanical pressure on the ground as animal trampling contributes to altered soil structure like soil compaction and reduction of soil porosity (Savadogo et al., 2007a; Kölbl et al., 2010; Dunne et al., 2011). These three factors contribute to vegetation biomass removable and in term expose the soils to the high intensity rain drop. That in turn disorganize soil particles and decrease soil stability (Hanson et al., 2004; Vega et al., 2008;
Haghighi et al., 2010). Nevertheless, on the clay soil of Tiogo, combination of grazing with fire and/or selective tree cutting did not affect infiltration rate. This suggests that siltyclay soils that are characterized by a more compact structure than the sandy soil is more adapted to the interaction of the combination of three disturbance factors. In this site, the moderate impact of the different interactions could also be explained by the synergic effect of the treatments combinations (Savadogo et al., 2008; Dayamba et al., 2011) that are leveling out each other. For example, the cooccurrence of fire and grazing has a synergistic effect on plant communities both in time and space. Burnt plots present postfire regrowth of grasses which in turn attracts grazers which reduce more the fuel load by consumption and trampling. And therefore could lower the intensity and frequency of the two factors.

\section{Management implication of the study}

For sustainable management of savanna in West Africa, prescribed early fire, selective tree cutting and controlled grazing are recommended as tools (Bellefontaine et al., 2000). In the context of climate change, these ecosystems could provide opportunities of carbon sequestration and sustain livelihoods of rural dwellers. The impact of these factors on vegetation is being documented (Zida et al., 2008, 2007; Savadogo et al., 2009, 2007b; Sawadogo et al., 2010, 2005, 2002; Dayamba et al., 2011, 2010). Therefore, their impact on soil stability which represent one of important pool of carbon had to be studied especially since erosion is considered as one of the major disturbance factor which affects SOC level (VandenBygaart and Angers, 2006). Infiltration rate is positively correlate with the soil stability and it ability to resist scouring (erosion) (Zhou et al., 2010). This result gave an overview of the effects of the different factors and show which one must need more control in eventual project for water properties improvement and/or carbon sequestration in these ecosystems. 


\section{Conclusion}

Ecosystems sustainability depends primarily on conservation of the soil and water resources. This study gave an overview of the effects of prescribed early fire, grazing and selective tree cutting on savannah woodland ecosystems.

The results indicated that Early fire and selective tree cutting affected differently steady infiltration and that there was site difference in terms of soil water properties. Early fire in Laba affected negatively water infiltration while in Tiogo, it did not have significant effect. As to selective tree cutting, it affected positively water infiltration in Laba while in Tiogo this effect was negative.

However, the main effects of grazing as well as the combining effect of the three factors (grazing, early fire and selective tree cutting) were negative on water infiltration both in the two sites.

Since infiltration rate is positively correlated with the soil stability and water condition, these results suggest that for long term sustainability of ecosystems, (i) grazing need more control in order to reduce its impact on soil stability and (ii). Selective tree cutting and fire impact depended of soils types, so their prescription may be redefined to take in consideration sites conditions.

Nevertheless, detailed field studies under a wide range of conditions will need to be investigated to support these findings.

\section{REFERENCES}

Are KS, Oluwatosin GA, Adeyolanu OD, Oke AO. 2009. Slash and burn effect on soil quality of an Alfisol: Soil physical properties. Soil Tillage Res., 103: 4-10.

Bassey Eze E, Imoke Eni D, Comfort O. 2011. Evaluation of the Infiltration Capacity of Soils in Akpabuyo Local Government Area of Cross River, Nigeria. J. Geogr. Geol., 3: 189-199.

Bellefontaine R, Gaston A, Petrucci Y. 2000. Management of Natural Forests of Dry Tropical Zones. Food and Agriculture Organization of the United Nations (FAO): Rome.
Beukes PC, Cowling RM. 2003. Nonselective grazing impacts on soilproperties of the Nama Karoo. J. Range Manag., 56: 547-552.

Castellano MJ, Valone TJ. 2007. Livestock, soil compaction and water infiltration rate: Evaluating a potential desertification recovery mechanism. $J$. Arid Environ., 71: 97-108.

Certini G. 2005. Effects of fire on properties of forest soils: a review. Oecologia, 143: $1-10$.

Chaichi MR, Saravit MM, Malekian A. 2005. Effects of Livestock Trampling on Soil Physical Properties and Vegetation Cover ( Case Study: Lar Rangeland, Iran ). Int. J. Agric. Biol., 7: 904-908.

Chartier MP, Rostagno CM, Pazos GE. 2011. Effects of soil degradation on infiltration rates in grazed semiarid rangelands of northeastern Patagonia, Argentina. J. Arid Environ., 75: 656-661.

Dayamba SD, Savadogo P, Sawadogo L, Tiveau D, Zida D, Tigabu M, Oden PC. 2010. Community dynamics and phytomass of herbaceous species in the Sudaniansavanna-woodlands of Burkina Faso: short-term impact of burning season. African J. Range Forage Sci., 27: 171-177.

Dayamba SD, Savadogo P, Sawadogo L, Zida D, Tiveau D, Oden PC. 2011. Dominant species' resprout biomass dynamics after cutting in the Sudanian savannawoodlands of West Africa: long term effects of annual early fire and grazing. Ann. For. Sci., 68: 555-564.

DeBano L. 2000. The role of fire and soil heating on water repellency in wildland environments: a review. J. Hydrol., 231232: 195-206.

Diawara S. 2012. Perturbations écologiques et fonctionnement des écosystèmes savanicoles: banques de semences du sol et propriétés physico- chimiques du sol. Université Polytechniques de Bobo Dioulasso, Bobo Dioulasso, p.83.

Driessen P, Deckers J, Spaargaren O. 2001. Lecture Notes on the Major Soils of the 
World. FAO World Soil Resources Reports-94, Rome.

Dunne T, Western D, Dietrich WE. 2011. Effects of cattle trampling on vegetation , in fi ltration, and erosion in a tropical. J. Arid Environ., 75: 58-69.

Haghighi F, Gorji M, Shorafa M. 2010. A study of the effects of land use changes on soil physical properties and organic matter. L. Degrad. Dev., 502: 496-502.

Hanson DL, Steenhuis TS, Walter MF, Boll J. 2004. Effects of soil degradation and management practices on the surface water dynamics in Talgua river watershed in Honduras. L. Degrad. Dev., 381: $367-381$.

Kölbl A, Steffens M, Wiesmeier M, Hoffmann C, Funk R, Krümmelbein J, Reszkowska A, Zhao Y, Peth S, Horn R, Giese M, Kögel-Knabner I. 2011. Grazing changes topography-controlled topsoil properties and their interaction on different spatial scales in a semi-arid grassland of Inner Mongolia, P.R. China. Plant Soil, 340: 35-58.

Makana J, Thomas SC. 2005. Effects of Light Gaps and Litter Removal on the Seedling Performance of Six African Timber Species 1. Biotropica, 37: 227237.

Martin DA, Moody, JA. 2001. Comparison of soil infiltration rates in burned and unburned mountainous watersheds. Hydrol. Process., 15: 2893-2903.

Pietola L, Horn R, Yli-Halla M. 2004. Effects of trampling by cattle on the hydraulic and mechanical properties of soil. Soil Tillage Res., 82: 99-108.

Sadeghi SHR, Vangah BG, Safaeeian NA. 2007. Comparison between effects of open grazing and manual harvesting of cultivated summer rangelands of northern Iran on infiltration, runoff and sediment yield. L. Degrad. Dev., 620: 608-620.

Savadogo P, Santi S, Dayamba SD, Nacro HB, Sawadogo L. 2012. Seasonal variation in fire temperature and influence on soil $\mathrm{CO} 2$ efflux, root biomass, and soil water properties in a Sudanian savanna-woodland, West Africa. Soil Res., 50: 195-206.

Savadogo P, Sawadogo L, Tiveau D. 2007a. Effects of grazing intensity and prescribed fire on soil physical and hydrological properties and pasture yield in the savanna woodlands of Burkina Faso. Agric. Ecosyst. Environ., 118: 8092.

Savadogo P, Tigabu M, Sawadogo L, Ode PC. 2009. Herbaceous phytomass and nutrient concentrations of four grass species in Sudanian savanna woodland subjected to recurrent early fire. Afr. J. Ecol., 699-710.

Savadogo P, Tiveau D, Sawadogo L, Tigabu M. 2008. Herbaceous species responses to long-term effects of prescribed fire, grazing and selective tree cutting in the savanna-woodlands of West Africa. Perspect. Plant Ecol. Evol. Syst., 10: 179-195.

Savadogo P, Zida D, Sawadogo L, Tiveau D. 2007b. Fuel and fire characteristics in savanna - woodland of West Africa in relation to grazing and dominant grass type. Int. J. Wildl. Fire., 16: 531-539.

Sawadogo L. 2009. Influence de facteurs anthropiques sur la dynamique de la vegetation des forêts classées de Laba et de Tiogo en zône soudanienne du Burkina Faso. Thèse d'état, UFR/SVTLBEV Université de Ouagadougou, Ouagadougou, p.181.

Sawadogo L, Nygård R, Pallo F. 2002. Effects of livestock and prescribed fire on coppice growth after selective cutting of Sudanian savannah in Burkina Faso. Ann. For. Sci., 59: 185-195.

Sawadogo L, Savadogo P, Tiveau D, Dayamba SD, Zida D, Nouvellet Y, Oden PC, Guinko S. 2010. Fire temperature and residence time during dry season burning in a Sudanian savanna-woodland of West Africa with implication for seed germination. J. For. Res., 21: 445-450. 
Sawadogo L, Tiveau D, Nygård R. 2005. Influence of selective tree cutting, livestock and prescribed fire on herbaceous biomass in the savannah woodlands of Burkina Faso, West Africa. Agric. Ecosyst. Environ., 105: 335-345.

VandenBygaart AJ, Angers DA. 2006. Towards accurate measurements of soil organic carbon stock change in agroecosystems. Can. J. Soil Sci., 86: 465-471.

Vega JA, Fonturbel T, Jime E, Ferna C. 2008. Immediate effects of prescribed burning, chopping and clearing on runoff, infiltration and erosion in a shrubland area in Galacia (NW SPAIN). $L$. Degrad. Dev., 515: 502-515.

Wagner S, Fischer H, Huth F. 2011. Canopy effects on vegetation caused by harvesting and regeneration treatments. Eur. J. For. Res., 130: 17-40.

Wuest SB. 2005. Bias in Ponded Infiltration Estimates Due to Sample Volume and Shape. Vadose Zo. J., 4: 1183-1190.
Zhou ZC, Gan ZT, Shangguan ZP, Dong ZB. 2010. Effects of grazing on soil physical properties and soil erodibility in semiarid grassland of the Northern Loess Plateau (China). Catena, 82: 87-91.

Zida D, Sawadogo L, Tigabu M, Tiveau D, Oden P, Ode PC. 2007. Dynamics of sapling population in savanna woodlands of Burkina Faso subjected to grazing, early fire and selective tree cutting for a decade. For. Ecol. Manage., 243: 102115 .

Zida D, Tigabu M, Sawadogo L, Tiveau D, Ode PC. 2008. Long-term effects of prescribed early fire, grazing and selective tree cutting on seedling populations in the Sudanian savanna of Burkina Faso. Afr. J. Ecol., 47: 97-108.

Zuur A, Leno E, Walker N, Saveliev A, Smith G. 2009. Mixed Effects Models and Extensions in Ecology with R. Springer: New York. 